\title{
New taxa and new records of Afrotropical Epermeniidae (Lepidoptera) with a distributional checklist
}

With 14 figures and 1 table

ReINHARD GAEDIKE ${ }^{1}$

${ }^{1}$ Florusstraße 5, 53225 Bonn, Germany. - tinagma@msn.com - c/o Senckenberg Deutsches Entomologisches Institut, Müncheberg Published on 2020-12-01

DOI:10.21248/contrib.entomol.70.2.359-364

LSID urn:Isid:zoobank.org:pub:D8D54724-6892-4BCA-B7BD-020A1145D14F

\section{Abstract}

The study of specimens, collected by DAVID AgAssiz in several African countries and in Madagascar, together with some specimens collected by WoLfRAM MEY, enabled not only the confirmation of some country records, but also the description of two new species (Epermenia (Calotripis) larseni and E. (C.) albofasciata), the description of the hitherto unknown female genitalia of Epermenia minuta GAEDIKE, 2004 and Ochromolopis namibica GAEDIKE, 2004, and the male genitalia of Ochromolopis xeropa (MEYRICK, 1909). Two first records (Africepermenia tanzanica GAEDIKE, 2004 and Phaulernis montuosa GAEDIKE, 2013) for Zimbabwe and one for Kenya (Epermenia triacuta GAEDIKE, 2013) were made. A distribution list showing hitherto known occurrence of the family in the Afrotropics is presented.

\section{Nomenclatural acts}

Epermenia (Calotripis) larseni spec. nov. - urn:lsid:zoobank.org:act:FD37A601-032A-472B-9599-9E6DBCE52738

Epermenia (Calotripis) albofasciata spec. nov. - urn:lsid:zoobank.org:act:EB6346C8-5761-4BFE-96F1-1FFD4B0A8FF0

\section{Key words}

Lepidoptera, distributional checklist, Epermeniidae

\section{Zusammenfassung}

Die Bearbeitung einer Ausbeute von DAvid AgAssiz aus verschiedenen Ländern Afrikas und aus Madagaskar sowie einiger von Wolfram Mey gesammelter Exemplare ergab neben der Bestätigung früherer Fundnachweise die Möglichkeit der Beschreibung von zwei neuen Arten (Epermenia (Calotripis) larseni und E. (C.) albofasciata), die Beschreibung der bisher unbekannten weiblichen Genitalien von Epermenia minuta GaEdIKe, 2004 und Ochromolopis namibica GAEDIKE, 2004 und der männlichen Genitalien von Ochromolopis xeropa (Meyrick, 1909). Für Zimbabwe konnten zwei Erstfunde (Africepermenia tanzanica GaEdike, 2004 und Phaulernis montuosa Gaedike, 2013) und für Kenia ein Erstfund (Epermenia triacuta GAEDIKE, 2013) gemacht werden. Die Verbreitungsliste zeigt den gegenwärtigen Stand der Verbreitung in der Afrotropischen Region. 


\section{Introduction}

The kindness of DAvid Agassiz enabled me to continue my studies on Afrotropical epermeniids (GAEDIKE, 1976; 2004a; 2004b; 2013). Together with some colleagues, he collected the specimens in several African countries and in Madagascar. Additionally, I had the opportunity to include in the present study the examination of some specimens collected by my colleague Wolfram Mey, Museum of Natural History, Berlin.

The study resulted in the discovery of two new species, the previously unknown females of two species, and the previously unknown male of one species. New country records for three species were established.

The hitherto known distribution of the family in the Afrotropics reflects more or less the the collection activities, it needs observations concerning the biology for a more detailed knowledge to the distributional pattern.

\section{Abbreviations}

BMNH British Museum (Natural History), London, U.K.

coll. Agassiz D. J. L. Agassiz, North Somerset, UK

RSA Republic of South Africa

SDEI Senckenberg Deutsches Entomologisches Institut, Müncheberg, Germany

ZMHB Museum für Naturkunde, Leibniz-Institut fürEvolutions-undBiodiversitätsforschung, Berlin, Germany

\section{Systematics}

\section{Africepermenia tanzanica GAEDIKE, 2004}

Zimbabwe: $10^{\star}, 1$ 을 Manicaland, Upper Bvumba $1680 \mathrm{~m}, 1^{\circ} 07^{\prime} 15^{\prime \prime S}, 32^{\circ} 46^{\prime} 10^{\prime \prime E}$, 3.xi.2016, [leg.] D. Agassiz \& K. Larsen: coll. Agassiz; $20^{\top} o^{\top}, 1$ 우, Manicaland, Bvumba 1360 m, 1903'33"S, 3243'41"E, 4.xi.2016, [leg.] D. Agassiz \& K. Larsen: coll. Agassiz; SDEI: first records for the country.

\section{Phaulernis montuosa GAEDIKE, 2013}

Zimbabwe: 1 ๙ $^{\star}$, Manicaland, Upper Bvumba $1680 \mathrm{~m}$, 1907'15"S, 3246'10"E, 4.xi.2016, [leg.] D. Agassiz \& K. Larsen: coll. Agassiz: first record for the country.

\section{Epermenia minuta GAEDIKE, 2004}

Madagascar: $2 \sigma^{\star} \sigma^{*}, 1$ ㅇ, 1 specimen without abdomen, Andasibe, $950 \mathrm{~m}, 18^{\circ} 57^{\prime} \mathrm{S} 48^{\circ} 25^{\prime} \mathrm{E}, 15 .-19.1 v .2018$, [leg.] D. Agassiz \& K. Larsen: coll. Agassiz; SDEI.
The material contains one female, which allows the description for the first time of the genitalia structure (Figs 3-4):

Proximal edge of segment VIII indented in the middle, ostium more strongly sclerotized, signum small, prolonged triangularly, the longest edge serrate.

\section{Epermenia paramalawica GAEDIKE, 2013}

Kenya: 2 우 우, Central Castle Forest lodge, 2050 m, $0^{\circ} 22^{\prime} 51^{\prime \prime S}, 37^{\circ} 18^{\prime} 35^{\prime \prime E}, 22 ., 23 . x .2013$, [leg.] Agassiz, Beavan, Heckford \& Larsen: coll. Agassiz

Epermenia (Calotripis) larseni spec. nov. urn:Isid:zoobank.org:act:FD37A601-032A-472B-9599-9E6DBCE52738

Holotype: $0^{\star}$, „Zimbabwe: Manicaland, Upper Bvumba, $1680 \mathrm{~m}, 1^{\circ} 07^{\prime} 15^{\prime \prime S}, 32^{\circ} 46^{\prime} 10^{\prime \prime E}$, 5.xi.2016, [leg.] A. Agassiz \& K. Larsen“; „Gen.präp. [genitalia slide] Gaedike 9682“; „Holotypus ơ, Epermenia larseni sp. n. det. R. Gaedike 2020“ BMNH.

Derivatio nominis: Named after my colleague Knud Larsen, one of the collectors of the new species.

Diagnosis (Fig. 1): Wingspan $12 \mathrm{~mm}$; head pale yellowish, laterally around eyes with some darker scales, labial palpus on inside with same coloration, on outside with dark brown scales, scape of antenna pale yellowish, with pecten, flagellum ringed; thorax and tegulae pale yellowish, basally overlaid with darker brown scales; forewing on dorsum with three tufts of raised scales at $1 / 3,1 / 2$ and $2 / 3$, at $3 / 4$ an indication of a fourth tuft, the largest at $1 / 3$; in the middle at $1 / 3,1 / 2$ and $3 / 4$ each a minute black dot, surrounded by white; ground coloration white, the apical half covered by light and darker brown pattern; brown in the area between half and $2 / 3$ from costa to the second and third tuft; light and darker brown in the area surrounding the second black dot and from third dot to apex; hindwing grey.

Male genitalia (Figs 5-7): Uncus slender, with pointed tip; tegumen with more strongly sclerotized edges; valva as long as uncus-tegumen, ampulla stout, nearly straight, with pointed tip, ventral edge more strongly sclerotized; border to valva strongly sclerotized, sacculus with apically rounded sclerotized tip below border; cucullus clearly longer than ampulla; phallus about two thirds of the length of valva, with a long thin cornutus.

Female genitalia: Unknown.

Remarks: Superficially similar to E. malawica, but the forewing with white ground colour, clearly visible on basal third, while in malawica the ground colour is pale 
ochreous. In the male genitalia the uncus slender, phallus clearly shorter than valva, while in malawica the uncus is stout and phallus as long as valva.

\section{Epermenia bulbosa GAEDIKE, 2004}

Kenya: 1 o $^{\star}$, Eastern Lewa, 2000 m, 08'25"N, 37²27'24"E, 10.-12.xii.2015, [leg.] D. Agassiz \& K. Larsen: coll. Agassiz.

\section{Epermenia agassizi GAEDIKE, 2013}

Kenya: 1 우, Central NaroMoru, 1945 m, 009'13"S, 3700'42"E, 3.-5.xii.2015, [leg.] D. Agassiz \& K. Larsen: coll. Agassiz.

\section{Epermenia triacuta GAEDIKE, 2013}

Kenya: $10^{\star}$, Eastern Lewa $2050 \mathrm{~m}, \quad 0^{\circ} 8^{\prime} 24,5^{\prime \prime} \mathrm{N}$, 37²7'23,8"E, 30.x.2013, [leg.] Agassiz, Beavan, Heckford \& Larsen: coll. Agassiz: first record for the country.

\section{Epermenia (Calotripis) albofasciata spec. nov.} urn:Isid:zoobank.org:act:EB6346C8-5761-4BFE-96F1-1FFD4BOA8FFO

Holotype: $0^{\star}$, Zimbabwe: Manicaland, Upper Bvumba, $1680 \mathrm{~m}, 1^{\circ} 07^{\prime} 15^{\prime} \mathrm{S}, 32^{\circ} 46^{\prime} 10^{\prime} \mathrm{E}, 4 . v i .2016$, [leg.] D. Agassiz \& K. Larsen; Gen.präp. [genitalia slide] Gaedike 9681: $\mathrm{BMNH}$.

Derivatio nominis: Named after the characteristic white stripe on the forewing.

Diagnosis (Fig. 2): Wingspan $16 \mathrm{~mm}$; head pale creamy, laterally around eyes dark brown; labial palpus directed obliquely upwards, the first two segments on outside dark brown, on inside pale creamy, apical segment totally creamy, only with single dark scales; scape of antenna creamy too, pecten nearly invisible; thorax and tegulae somewhat darker creamy than the head, tegulae basally and thorax apically with dark brown scales; forewing nearly black with clear white pattern; dorsum with three tufts of raised scales at $1 / 3$ (the largest), $1 / 2$ and $2 / 3$; a broad white stripe from base of dorsum oblique to costa in the basal third of wing, interrupted by black patch near the base; between first and third tuft from dorsum to cell a white area, the border to cell with some light brown scales, also white are a smaller patch on costa at $3 / 4$, a patch subapically, surrounded by black to apex and a thin stripe in the middle of termen; apically the cell with a small light brown patch, three black dots in the middle of wing, above the three tufts; hindwing shiny light grey.
Male genitalia (Figs 8-10): Uncus long, straight, basally rounded and laterally with small bristles; tegumen more strongly sclerotized on edges and in the middle; valva as long as uncus + tegumen, ampulla straight, clearly shorter than cucullus, apically blunt, covered with numerous bristles, ventral edge somewhat more strongly sclerotized, the sclerotized border with a prolongation to cucullus; sacculus apically with thin pointed tip, phallus clearly shorter than valva, slightly curved, with very thin cornutus. Female genitalia: Unknown.

Remarks: Superficially distinguishable from the other Afrotropical members of the genus by the large wingspan and the characteristic forewing pattern. In the genitalia structure the clearly distinctive characters for this species are the basally rounded and bristled uncus and the straight and blunt ampulla.

\section{Ochromolopis xeropa (MEYRICK, 1909)}

RSA: 1 ơ, West Cape, N Montagu, Burger Pass, 27.xi.2013, leg. W. Mey; ZMHB; 1 + , West Cape, Villiersdorp, WolfKloof, 26.ii.2014, leg. W. Mey: ZMHB.

The studied material contains the first known male specimen, which allows description of the genitalia structure (Figs 11-13):

Uncus long, straight, at $1 / 3$ from base laterally each with small bristled area, tip rounded, with dentate edge, tegumen with more strongly sclerotized edges; valva as long as uncus and tegumen, from broad base narrowing to rounded tip, longitudinally folded, basal end of costal edge more strongly sclerotized, costal arm basally with upwardly directed rounded tip, apex dorsally enlarged and rounded, ventrally prolonged to a pointed tip; phallus nearly as long as valva, vesica with a large area with dense thin thorns, subapically a smaller area with some isolated larger and smaller thorns, in the apical half a narrow rod-shaped sclerotizaion.

\section{Ochromolopis namibica GAEDIKE, 2004}

1 ㅇ, Namibia, Gamsbg., Northern slope, 28.i.2007, LF [lux], leg. Mey \& Ebert, Gen.präp. [genitalia slide] Gaedike 7030: ZMHB; 1 ㅇ, Namibia, Auers mts, Windhoek, 1917 m, 25.i.2009, leg. W. Mey, Gen.präp. [genitalia slide] Gaedike 7530: ZMHB.

The studied material contains for the first time female specimens, which allow the description of the genitalia structure (Fig. 14):

Ventral arms of anterior apophysae connected by a more strongly sclerotized narrow band, dorsal arms ending in a more or less square area, covered by minute thornlike sclerotizations; ductus bursae proximally more strongly sclerotized; laterally on each side of the ostium a round somewhat more strongly sclerotized patch on segment VIII. 

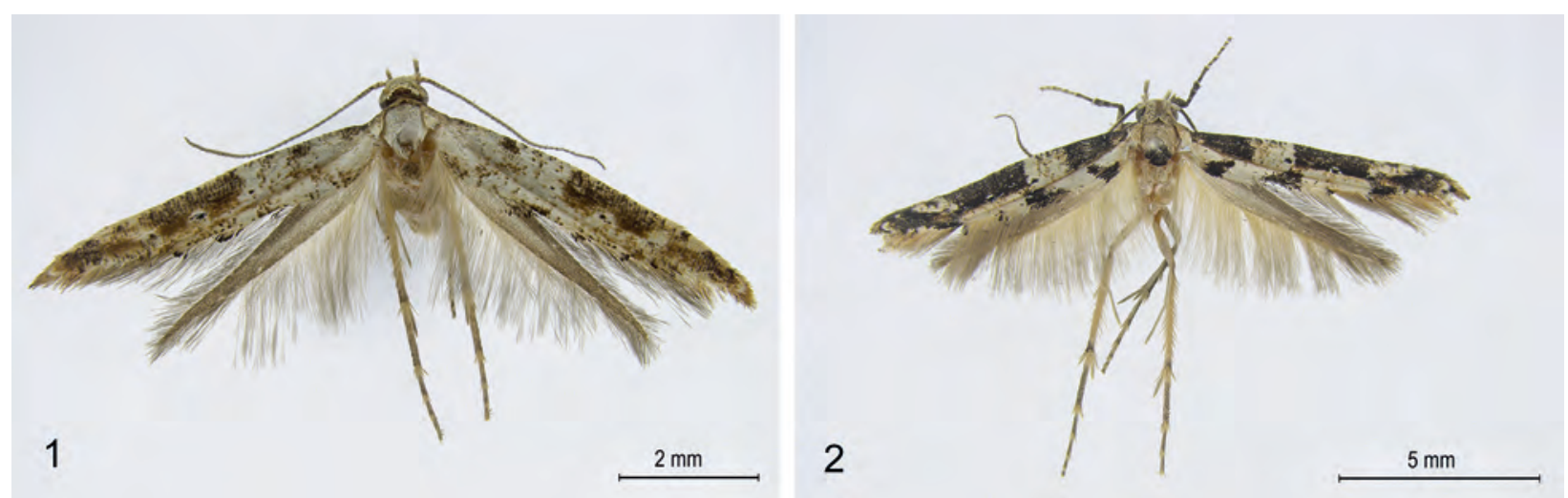

Figs 1-2: 1 - Epermenia (Calotripis) larseni; 2 - Epermenia (Calotripis) albofasciata.

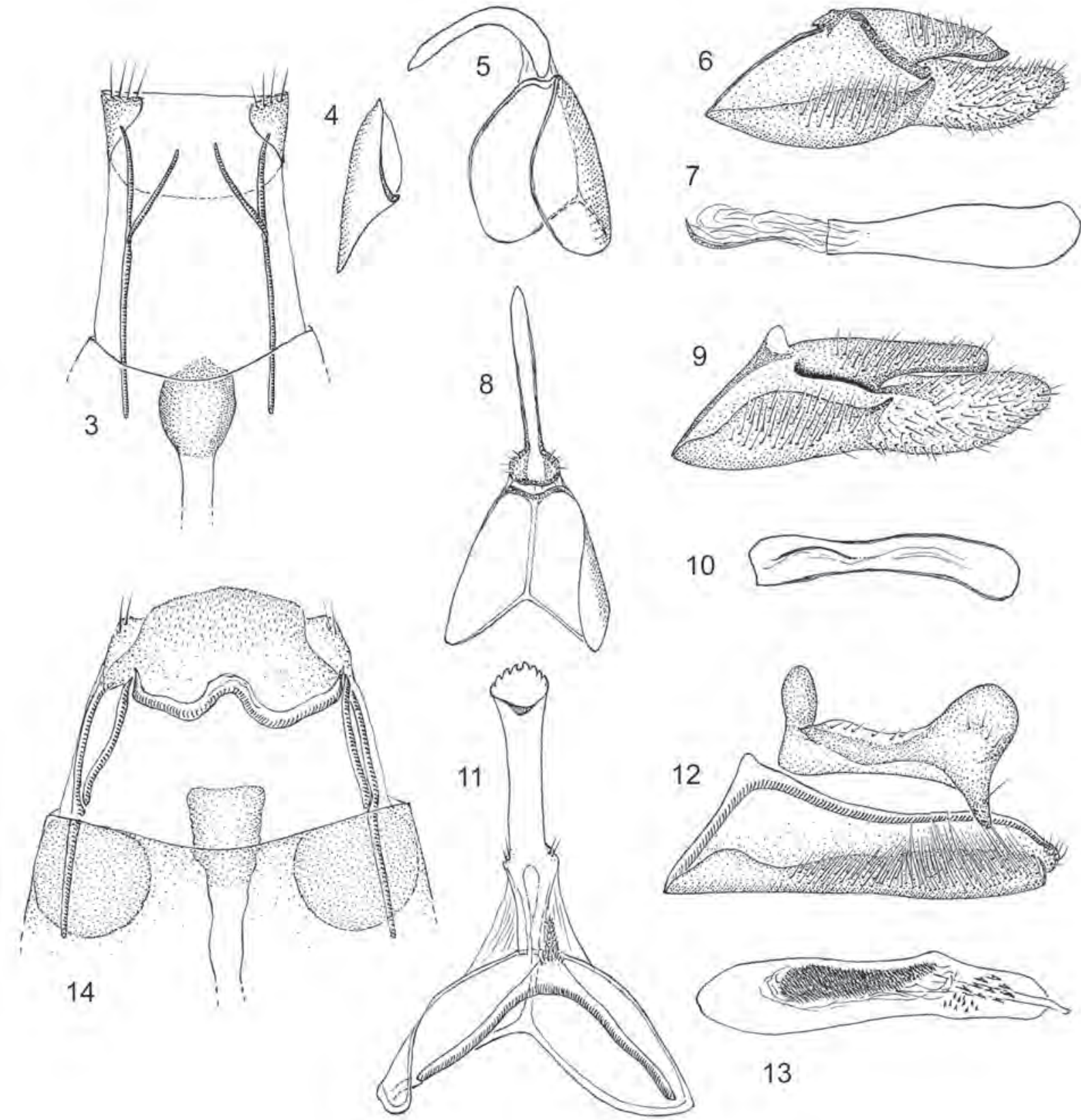

Figs 3-14: Epermenia minuta (female: 3 - segment VIII, 4 - signum); Epermenia larseni (male: 5 - uncus-tegumen, 6 - valva, 7 - phallus); Epermenia albofasciata (male: 8 - uncus-tegumen, 9 - valva, 10 - phallus); Ochromolopis xeropa (male: 11 - uncustegumen, 12 - valva, 13 - phallus); Ochromolopis namibica (female: 14 - segment VIII). 
Tab. 1: Distribution list of the Epermeniidae of the Afrotropical Region (new records in Bold text).

\begin{tabular}{|c|c|}
\hline Taxa & Distribution \\
\hline Africepermenia tanzanica GAEDIKE, 2004 & Tanzania; Kenya; Zimbabwe \\
\hline Mesepermenia malgachica GAEDIKE, 2004 & Madagascar \\
\hline Inuncus juratae GAEDIKE, 2013 & Kenya; Tanzania \\
\hline Phaulernis montuosa GaEdike, 2013 & Kenya; Zimbabwe; Tanzania; Malawi; Uganda \\
\hline P. africana GAEDIKE, 2013 & Kenya; Tanzania \\
\hline Epermenia (Calotripis) minuta GAEDIKE, 2004 & Madagascar \\
\hline E. (C.) criticodes MEYRICK, 1913 & RSA; Kenya \\
\hline E. (C.) griveaudi GAEDIKE, 2004 & Madagascar \\
\hline E. (C.) conioptila Meyrick, 1921 & Zimbabwe; Kenya \\
\hline E. (C.) maculata GAEDIKE, 2004 & Madagascar \\
\hline E. (C.) meyi GAEDIKE, 2004 & Malawi; Kenya; Ethiopia \\
\hline E. (C.) brevilineolata GAEDIKE, 2004 & Madagascar \\
\hline E. (C.) malawica Gaedike, 2004 & Malawi; Kenya \\
\hline E. (C.) larseni sp. n. & Zimbabwe \\
\hline E. (C.) paramalawica GaEdike, 2013 & Kenya \\
\hline E. (C.) karurucola GAEDIKE, 2013 & Kenya \\
\hline E. (C.) formosa GAEDIKE, 2013 & Kenya \\
\hline E. (C.) dallastai GAEDIKE, 2013 & Kenya \\
\hline E. (C.) costomaculata GAEDIKE, 2013 & Kenya \\
\hline E. (C.) turicola GAEDIKE, 2013 & Kenya; Tanzania \\
\hline E. (C.) hamata GAEDIKE, 2013 & RSA \\
\hline E. (C.) aarviki GAEDIKE, 2013 & Tanzania; Kenya \\
\hline E. (C.) ruwenzorica GAEDIKE, 2013 & Dem. Rep. Congo \\
\hline E. (C.) bulbosa GAEDIKE, 2004 & RSA; Kenya \\
\hline E. (C.) bicornis GAEDIKE, 2004 & RSA \\
\hline E. (C.) oriplanta BRADLEY, 1965 & Uganda \\
\hline E. (C.) philoritis (BradLey, 1965) & Uganda \\
\hline E. (C.) epirrhicna MEYRICK, 1938 & Dem. Rep. Congo \\
\hline E. (C.) tenuipennella GaEdike, 2013 & Kenya \\
\hline E. (C.) agassizi GAEDIKe, 2013 & Kenya \\
\hline E. (C.) albofasciata sp. $\mathrm{n}$. & Zimbabwe \\
\hline E. (Cataplectica) mineti GAEDIKE, 2004 & Madagascar \\
\hline E. (C.) kenyacola GaEdike, 2013 & Kenya; Malawi; Dem. Rep. Congo \\
\hline E. (C.) triacuta GAEDIKE, 2013 & Namibia; Kenya \\
\hline $\begin{array}{l}\text { E. (C.) iniquella (Wocke, 1867) } \\
=\text { ochrodesma MEYRICK, } 1913\end{array}$ & RSA; Kenya \\
\hline Gnathifera proserga (MEYRICK, 1913) & RSA \\
\hline G. punctata GAEDIKE, 2013 & RSA \\
\hline $\begin{array}{l}\text { Ochromolopis xeropa (MEYRICK, 1909) } \\
\text { = praefumata MEYRICK, } 1911\end{array}$ & RSA \\
\hline O. pallida GAEDIKE, 2004 & Madagascar \\
\hline O. ithycentra (MEYRICK, 1926) & RSA \\
\hline
\end{tabular}




\begin{tabular}{|l|l|}
\hline \multicolumn{1}{|c|}{ Taxa } & \multicolumn{1}{c|}{ Distribution } \\
\hline O. namibica GAEDIKe, 2004 & Namibia, RSA \\
\hline O. sagittella GAEDIKe, 2013 & Kenya \\
\hline O. cana GAEDIKE, 2013 & RSA \\
\hline
\end{tabular}

\section{Acknowledgements}

I thank A. D. Liston (Müncheberg) for linguistic corrections and $\mathrm{CH}$. Kutzscher (Müncheberg) for preparing the colour photographs.

\section{References}

Gaedike, R. 1976: Die Epermeniidae der äthiopischen Region (Lepidoptera). - Beiträge zur Entomologie 26 (2): 451-454, 11 Fig.

GAEDIKE, R. 2004a: New genera and species of epermeniid moths from the Afrotropical Region (Lepidoptera: Epermeniidae). - Annals of the Transvaal Museum 41: 41-59, 66 figs.

Gaedike, R. 2004b: Epermeniidae (Lepidoptera, Epermenoidea). - Esperiana Memoir 1: 199-202, 7 figs, col. pl. 6 (figs 4-6).

GAEDIKE, R. 2013: New or poorly known Epermeniidae of the Afrotropis (Lepidoptera, Epermenioidea). - Contributions to Entomology 63 (1): 149-168, 105 figs. 